\title{
SEJARAH LOKAL DAN PENDIDIKAN KARAKTER (TINJAUAN DALAM KEARIFAN LOKAL MASYARAKAT SASAK LOMBOK)
}

\author{
${ }^{1}$ Lalu Murdi \\ ${ }^{1}$ Universitas Hamzanwadi \\ lalumurdi@ymail.com
}

\begin{abstract}
Abstrak
Kearifan lokal adalah bagian dari kearifan bangsa yang dapat menjadi landasan pendidikan karakter. Kearifan lokal masyarakat Sasak Lombok yang sudah mengakar dalam sejarah suku bangsanya memiliki nilai universal, sehingga proses engkulturasi perlu dilakukan pada masyarakat mulai dari sekolah dasar sampai pendidikan karakter orang dewasa. Tulisan ini bertujuan untuk menganalisa pentingnya kearifan lokal (local wisdom) sebagai landasan dari pendidikan karakter tersebut, sekaligus menawarkan pemahaman konsep dan praktik bagaimana seharusnya pendidikan karakter yang berakar pada budaya lokal tersebut diimplementasikan dalam dunia pendidikan.
\end{abstract}

Kata Kunci: Sejarah Lokal, Kearifan Lokal, Pendidikan Karakter.

\section{PENDAHULUAN}

Think globally and and act locally merupakan ungkapan yang biasanya didengungkan untuk menjaga kearifan lokal dalam kehidupan sehari-hari. Hal ini penting untuk diperhatikan bersama di era globali ini, dimana identitas sebagai suatu bangsa terkadang kabur, terkikis, bahkan dikatakan tidak sesuai dengan zamannya. Logikanya memang benar bahwa kehidupan manusia tersebut baik dalam infrastruktur sosial, struktur sosial, maupun suprastruktur sosial masyarakat tidaklah pasif, dan selalu terjadi perubahan. Akan tetapi perubahan yang terjadi tentu berbeda-beda, ada yang berakulturasi dengan budaya baru, di lain hal terkadang terjadi asimilasi. Pada intinya, kita cukup mengatakan "mempertahankan apa yang baik dari kebudayaan kita, dan mengambil apa yang baik dan sesuai dari kebudayaan lain” dalam hal ini misalnya budaya Barat yang dalam banyak hal tidak sesuai dengan budaya ketimuran kita.

Skinner menyebutkan adanya lebih dari 35 suku-bangsa di Indonesia, masingmasing dengan bahasa dan adat yang tidak sama (dalam Nasikun, 2011: 44). Ke- 35 suku bangsa tersebut tersebar pada kurang lebih 3.000 pulau, bahkan lebih banyak lagi, Sri Edi Swasono (2014) mencatat tidak kurang dari 501 suku bangsa di Indonesia yang masing-masing memiliki kekhasan tersendiri. Semua ini menjadi identitas tersendiri bagi bangsa Indonesia untuk menjunjung tinggi kearifan lokal yang dimiliki oleh setiap 
Sejarah Lokal ..... - Lalu Murdi

suku, agama dan budaya yang ada tersebut. Tentu kerafan lokal yang berbeda itulah yang menjadi identitas Keindonesiaan kita.

Jelas bahwa budaya lokal/kearifan lokal merupakan bagian dari budaya/kearifan nasional. Karena itu untuk memperkuat identitas bangsa, terlebih dahulu harus memperkuat identitas lokal sebagai basis identitas nasional. Jika logikanya demikian, bagaimana dengan pendidikan karakter yang akhir-akhir ini semakin boming ditengahtengah masyarakat. Inilah saatnya kita kembali pada ungkapan Presiden Pertama RI, Soekarno tentang 'nation and character building' kembali menemukan relevansinya.

Kearifan lokal sebagai bagian dari pendidikan karakter sudah mengakar dalam sejarah yang panjang. Karena itu, mempelajari sejarah merupakan bagian panting untuk menemukan kearifan tersebut. Sehingga wajar jika dikatakan bahwa guna sejarah yang pertama adalah sebagai pelajaran (Hariyono, 1995). Atau meminjam istilahnya Kuntowijoyo (2005), bahwa relevansi sejarah sebagai pendidikan karakter adalah sebagai "pendidikan moral dan pendidikan kebijakan".

Pendidikan karakter yang sudah mengakar dalam sejarah yang panjang tersebut, dengan demikian dapat dikatakan juga sebagai sebuah proses engkulturasi dari budaya lokal yang ada (Soekanto, 1993: 167). Karena begitu pentingnya jati diri bangsa ini untuk membangun karakternya, maka paling tidak setelah Indonesia merdeka sampai saat ini, lagi-lagi seperti yang diharapkan pounding father kita yaitu selain membangun bangsa dari segi politik, ekonomi, dan infrastruktur, dan yang lebih penting lagi dan diakui sangatlah penting yaitu membangun karakter bangsa. Secara kontinue, mulai dari ekonomi, infrastruktur dan lain sebagainya, pembangunan karakter bangsa kita harus dan sangat perlu untuk ditingkatkan.

Sejalan dengan hal tersebut, masyarakat Sasak Lombok secara khusus sama dengan suku-bangsa lainnya memiliki kearifan lokal tersendiri yang sudah mengakar dalam perjalanan sejarahnya. Kearifan lokal yang dimiliki masyarkat Sasak tersebut dalam banyak aspek dapat dijadikan salah satu basis pendidikan karakter dewasa ini khususnya dalam lingkup lokalitas, mulai dari sistem pemerintahan, sistem kebersamaan masyarakat, hukum-hukum, sistem pergaulan hidup sehari-hari dan lain sebagainya.

\section{KONSEP KEARIFAN LOKAL}

Kearifan lokal dapat didefinisikan sebagai suatu kekayaan budaya lokal yang mengandung kebijakan hidup; pandangan hidup (way of life) yang mengakomodasi 
Sejarah Lokal ..... - Lalu Murdi

kebijakan (wisdom) dan kearifan hidup. Di Indonesia yang kita kenal sebagai Nusantara. Kearifan lokal itu tidak hanya berlaku secara lokal pada budaya atau etnik tertentu, tetapi dapat dikatakan bersifat lintas budaya atau lintas etnik sehingga membentuk nilai budaya yang bersifat nasional. Sebagai contoh, hampir di setiap budaya lokal di Nusantara dikenal kearifan lokal yang mengajarkan gotong royong, toleransi, etos kerja, dan seterusnya. Pada umumnya etika dan nilai moral yang terkandung dalam kearifan lokal diajarkan turun-temurun, diwariskan dari generasi ke generasi melalui sastra lisan (antara lain dalam bentuk pepatah dan peribahasa, folklore), dan manuskrip (http://badanbahasa.kemdikbud.go.id/).

Kearifan lokal pada setiap daerah memiliki kecendrungan-kecendrungan tersendiri yang tentunya mengandung nilai karakter. Baik sebagai nilai dalam kepemimpinan, nilai dalam bergaul dan lain-lain. Kearifan lokal tersebut sudah mengakar jauh dalam sejarah setiap suku bangsa yang ada, begitu juga halnya dengan kearifan lokal masyarakat Sasak Lombok merupakan perwujudan dari pergaulan hidup yang sudah terbentuk dari pengalaman hidup masyarakatnya sejak dahulu kala.

Beberapa contoh kearifan lokal masyarakat Sasak seperti yang akan diuraikan selanjutnya, dengan sendirinya dapat dipahami bahwa selain mengandung unsur-unsur lokal, sekaligus mengandung pandangan hidup nasional, bahkan dalam tataran ideal memiliki nilai yang universal. Belum lagi kearifan lokal lainnya yang mengandung nilai-nilai karakter bangsa, sehingga jelas bahwa nilai-nilai lokalitas tersebut sangat perlu mendapat perhatian yang lebih serius dalam banyak aspek, terutama sekali sebagai landasan karakter bangsa dan landasan lokalitas dimana konsep tersebut tumbuh, dikembangkan dan diinternalisasikan oleh masyarakatnya.

Berdasarkan hal tersebut di atas, karena penanaman karakter untuk saat ini lebih banyak dibebankan kepada sekolah, dengan sendirinya sekolah harus banyak memperhatikan pendidikan karakter anak didiknya. Karena itu, seorang guru terutama sekali yang secara substansial mengajarkan pendidikan karakter, misalnya mata pelajaran PPKn dan sejarah sangat penting untuk memahami konsep-konsep budaya lokal yang dimilikinya. Sehingga ketika menjelaskan konsep karakter yang sifatnya nasional dapat dikaitkan dengan konsep kebudayaan lokalnya. Dengan demikian diharapkan siswa akan lebih cepat memahami dan dapat menginternalisasikan dalam kehidupannya sehari-hari. 
Melalui proses pendidikan kearifan lokal di atas, sebagai basis dari pendidikan karakter yang diteransformasikan ke dalam dunia pendidikan, paling tidak budaya lokal tersebut dapat menghasilkan kearifan lokal sebagai berikut:

1. Mampu bertahan terhadap budaya luar,

2. Memiliki kemampuan mengakomodasi unsur-unsur budaya luar,

3. Memunyai kemampuan mengintegrasikan unsur budaya luar ke dalam budaya asli,

4. Memunyai kemampuan mengendalikan,

5. Mampu memberi arah pada perkembangan budaya (http://salamannennungeng.blogspot.com.).

Sedangkan bagi siswa, dengan menggunakan kearifan lokal untuk menjelaskan konsep pendidikan karakter nasional, diharapkan:

1. Lebih memahami karakter lokalitas daerahnya yang memberi warna terhadap karakter nasional bangsa kita.

2. Lebih mudah diinternalisasikan, karena secara psikologis merasa memiliki.

3. Dapat menjadi manusia yang berpikiran global, dan memiliki kepribadian lokal.

4. Ketika bergaul dengan masyarakat luar, mampu menunjukkan kepribadian lokal dan nasional pada umumnya.

Adapun berkaitan dengan sejarah yang merupakan basis kearifan lokal sebagai pendidikan karakter, dijelaskan oleh Finberg (dalam Widja, 1991), bahwa lingkungan keluarga, lingkungan komunitas perlu dikaji dengan mengacu pada lingkaran di luarnya yang lebih besar. Dengan kata lain bahwa untuk mengetahui kesatuan yang lebih besar (misalnya Pancasila sebagai filosofi dasar karakter Bangsa), bagian yang lebih kecil itupun harus dimengerti dengan baik.

\section{PENDIDIKAN KARAKTER PADA MASYARAKAT SASAK}

Sebagai masyarakat yang berbudaya, dalam segala aspek kehidupannya masyarakat Sasak memiliki kearifan lokal yang sangat baik untuk ditransformasikan dalam pendidikan generasi muda dewasa ini. Kearifan lokal tersebut sudah terbentuk dalam perjalanan sejarah masyarakatnya yang cukup lama. Sekedar beberapa contoh dari kearifan lokal yang berakar dalam masyarakat Sasak dan dapat dijadikan bagian dari pendidikan karakter, coba diuraikan dalam tulisan ini. 
Sejarah Lokal ..... - Lalu Murdi

Pertama, sistem pemerintahan. Setidaknya dalam hal ini masyarakat kita perlu menelusuri aspek-aspek dari hukum adat Sasak yang diterapkan oleh salah seorang raja di gumi Sasak pada zaman dahulu. Berdasarkan cerita yang ada, saking patuhnya sang raja menjalankan peraturan yang telah ditetapkan bersama, sang raja berani menetapkan sanksi hukuman yang harus dijalankan jika sekiranya sang raja melanggar hukum. Raja tersebut tidak lain adalah raja Surya Alam.

Seperti dijelaskan Sudirman, Bahrie, dan Lalu Ratmaja (2012: 2), disinyalir bahwa Raja Surya Alam adalah salah seorang raja Selaparang yang bercorak Islam. Untuk menerapkan aturan-aturan tentang hukum dan tata pemerintahan, kedatuan Selaparang menggunakan acuan yang ditetapkan dalam sebuah kitab undang-undang yang dinamakan Kitab Lontar Kotaragama. Dalam kitab tersebut dikisahkan kepatuhan Raja Surya Alam beserta seluruh rakyatnya menjalankan peraturan sehingga Raja Surya Alam sangat disegani, ditakuti dan dipatuhi rakyatnya.

Secara garis besar, naskah Kotaragama terdiri atas tiga bagian: 1) tata cara atau persyaratan pejabat kepemerintahan; 2) hukum-hukum; 3) denda apabila hukum-hukum dilanggar. Bagian pertama yang berkaitan tentang sifat-sifat Raja Surya Alam, dapat dikutif sebagai contoh.

"Raja harus selalu berpedoman pada syariat agama, bersifat sosial (gemar bersedah), memberikan pengayoman, disiplin (tidak ingkar janji), harus selalu meningkatkan pengetahuannya (menuntut ilmu), mencegah terjadinya malapetaka, danta danti kusuma warsa, tidak suka kawin dan adil (gonta-ganti pasangan) (Sudirman, Bahrie, dan Lalu Ratmaja, 2012: 2).

Kedua, solidaritas sosial masyarakat. Perubahan yang mengarahkan masyarakat dewasa ini pada pola hidup yang materialistis dan pada akhirnya semakin mengikis adanya kehidupan dalam kebersamaan, menyebabkan pentingnya generasi muda saat ini memahami dan menginternalisasi nilai-nilai kebersamaan masyarakat Sasak yang sudah mengakar dalam sejarah masyarakatnya.

Istilah-istilah besiru, banjar, serta beberapa sistem tolong menolong lainnya seperti pada saat membuat rumah, kerjasama dalam membuat tempat ibadah, membuat sarana pendidikan, gotong royong dalam acara pernikahan, kematian, dan lain sebagainya, merupakan beberapa bagian kecil dari sistem kebersamaan masyarakat Sasak. Dalam buku "Nilai Kebersamaan Masyarakat Sasak (Refresentasi Besiru, Banjar, dan Sistem Gotong Royong Lainnya)”, Lalu Murdi (2014), menjelaskan bahwa sistem sosial seperti halnya sistem besiru, pembentukan kelompok banjar, gotong royong dalam membuat rumah, tempat umum, dan lain sebagainya tersebut merupakan 
Sejarah Lokal ..... - Lalu Murdi

bagian penting dari kearifan lokal masyarakat Sasak sehingga dapan hidup dengan persatuan sosial yang cukup tinggi. Belum lagi beberapa konsep yang sudah lumrah didengar seperti saling laiq/pete (saling mengunjungi), saling tanjaq (saling memberi), saling pesilaq (saling undang ketika ada hajatan dan lain sebagainya), dan lain sebagainya.

Ketiga, larangan-larangan. Salah satu contoh adalah perilaku yang dianggap tabu dalam pergaulan, seperti menghindari kata kamu, mengambil atau memegang dengan tangan kiri, bersiul di malam hari, memegang kepala, telinga, dan pundak, mengumpat, berludah dan lain sebagainya. Keempat, tata krama dan sopan santun dalam pergaulan. Konsep tindih pada masyarakat Sasak sesungguhnya merupakan bagian dari nilai budaya luhur dalam sopan santun pergaulan yang dimilikinya. Tindih, merupakan sikap kehati-hatian dalam bertutur kata dan berbuat. Dapat pula diartikan sebagai suatu keadaan kepribadian yang memiliki kesungguhan untuk mempertahankan suatu kebenaran, kebaikan, keindahan, dan keluhuran (Ratmaja, 2011: 91).

Bagaimana tata kelakuan di lingkungan pergaulan keluarga dan masyarakat pada masyarakat Suku Sasak yang merupakan perwujudan dari sifat tindih tersebut dijelaskan dalam bukunya Abdurrachman May, dkk (1989), yang pada intinya bahwa tata karma dalam pergaulan masyarakat Sasak sudah dibina dari keluarga inti sampai dalam lingkungan masyarakat yang meliputi banyak hal seperti dalam pemerintahan, pendidikan, ekonomi, dan adat sendiri.

Mencermati sedikit contoh dari kearifan lokal yang dimiliki masyarakat di atas, barangkali sudah waktunya setiap orang tua, masyarakat pada umumnya, serta lembaga pendidikan coba merumuskan bagaimana kearifan lokal yang sudah mengakar dalam sejarah masyarakat Sasak tersebut dapat dienkulturasikan oleh generasi muda kita saat ini dan yang akan datang.

\section{PENTINGNYA PENDIDIKAN KARAKTER}

Multikrisis yang melanda bangsa kita saat ini tentunya dapat dikatakan sedang membutuhkan pendidikan karakter, bukan hanya untuk pendidikan anak sejak dini, melainkan pendidikan bagi orang dewasa yang tentu sangat mengerti dengan karakter bangsa dalam tataran konsep saja. Kasus sebagai berikut dapat menjadi contoh: '158 kepala daerah tersangkut korupsi sepanjang 2004-2011; 42 anggota DPR terseret korupsi pada kurun waktu 2008-2011; 30 anggota DPR periode 1999-2004 terlibat kasus suap pemilihan DGS BI; Kasus korupsi terjadi diberbagai lembaga seperti 
Sejarah Lokal ..... - Lalu Murdi

KPU,KY, KPPU, Ditjen Pajak, BI, dan BKPM (http://www.pendidikankarakter.com). Kasus-kasus ini merupakan bukti dari pentingnya pendidikan orang dewasa, dan orang yang mengerti mengenai karakter. Belum lagi para remaja, yang notabene-nya seorang pelajar yang sedang membutuhkan pembinaan karakter. Paling tidak secara umum, khususnya bagi para pelajar pentingnya pendidikan karakter tersebut dikarenakan beberapa hal sebagai berikut:

\section{Melemahnya ikatan keluarga}

Dengan demikian, sekolah telah berganti peran menjadi mengganti keluarga di dalam memperkenalkan nilai-nilai moral yang tidak lagi diperoleh oleh anak dalam keluarga. Dalam hal ini sekolah telah mempunyai tugas ganda selain tugas pokoknya mengajar tetapi juga mendidik.

\section{Kecendrungan negatif di dalam kehidupan remaja dewasa ini}

Hal ini dipengaruhi banyak faktor, mulai dari melemahnya ikatan keluarga di atas, lemahnya kontrol keluarga, pengaruh media yang begitu kuat, dan lain sebagainya. Sehingga para remaja seolah kehilangan jati dirinya. Suatu kebangkitan kembali dari perlunya nilai-nilai etik, moral, dan budi pekerti dewasa ini (Zuriah, 2007: 10-11).

Apabila ada yang mengatakan bahwa abad ke-21 Tuhan akan mati dan tergantikan oleh IPTEK, ramalan masa depan tersebut sepertinya gagal. Jiwa manusia memang memiliki nilai tersendiri, terutama nilai Ketuhanan. Karena itu, masyarakat secara global, dengan melihat kemunduran karakter saat ini, sangat membutuhkan pendidikan karakter tersebut, terutama sekali yang bersumber dari nilai Ketuhanan. Dalam hal ini, bagi masyarakat dan pelajar Muslim membutuhkan nilai moral dari AlQur'an sebagai pedoman hidup, dan karakter bangsa yang membumi dengan kandungan kitab suci tersebut.

Jelas bahwa perkembangan ilmu pengetahuan di satu sisi sangatlah penting, akan tetapi pendidikan dan penanaman karakter pada sisi lain sangatlah berguna sebagai pedoman hidup yang mengarahkan IPTEK. Karena itu, Theodore Roosevelt mengatakan: "To educate a person in mind and not in morals is to educate a menace to society" (Mendidik seseorang dalam aspek kecerdasan otak dan bukan aspek moral adalah ancaman mara-bahaya kepada masyarakat) (http://www.pendidikankarakter.com).

\section{ASAS KURIKULUM PENDIDIKAN KARAKTER DALAM KERARIFAN LOKAL}


Sejarah Lokal ..... - Lalu Murdi

Landasan filosofis dan landasan sosiologis adalah yang paling dekat untuk menganalisa hal ini. Sebagai landasan filosofis, Pancasila merupakan dasar pendidikan kita di Indonesia. Pancasila yang merupakan pandangan hidup bangsa kita dengan jelas mengandung karakter bangsa yang tercermin dalam dimensi multikultur, dari kearifan lokal yang terpola dalam karakter bangsa secara nasional. Karena itu, Pancasila sebagai landasan filosofis bangsa menjadi landasan pengembangan kurikulum pendidikan karakter kita di Indonesia. Dalam hal ini isi yang terkandung di dalamnya dapat menjadi barometer dan indikator pencapaian kurikulum pendidikan yang berkarakter tersebut. Berikut merupakan uraian dari Pancasila sebagai pedoman karakter bangsa:

Mengenai sila ke-Tuhanan Yang Maha Esa diberi uraian sebegai berikut:

1. Percaya dan takwa kepada Tuhan Yang Maha Esa sesuai dengan agama dan kepercayaan masing-masing.

2. Hormat-menghormati dan bekerja-sama antara pemeluk agama yang lain.

3. Saling menghormati kebebasan menjalankan ibadah sesuai dengan agamanya.

4. Tidak memaksakan suatu agama dan kepercayaan kepada orang lain.

Sedangkan sila kemanusiaan yang adil dan beradab adalah:

1. Mengakui persamaan derajat, persamaan hak, dan persamaan kewajiban antara sesama manusia.

2. Saling mencintai sesama manusia.

3. Mengembangkan sikap tenggang rasa.

4. Menjunjung tinggi nilai kemanusiaan.

5. Berani membela kebenaran dan keadilan.

6. Mengembangkan sikap hormat dan bekerjasama dengan bangsa lain, dan lainlain.

Lebih lanjut mengenai Sila Persatuan Indonesia sebagai berikut:

1. Menempatkan persatuan, kesatuan, kepentingan, dan keselamatan bangsa dan negera di atas kepentingan pribadi atau golongan.

2. Rela berkorban untuk kepentingan bangsa dan negara.

3. Cinta Tanah Air dan Bangsa, dan lain-lain.

Sila Kerakyatan yang Dipimpin oleh Hikmah Kebijaksanaan dalam Permusyawaratan/ Perwakilan.

1. Mengutamakan kepentingan negara dan masyarakat.

2. Tidak memaksakan kehendak kepada orang lain.

3. Mengutamakan musyawarah dalam mengambil keputusan. 
Sejarah Lokal ..... - Lalu Murdi

4. Musyawarah diliputi oleh semangat kekeluargaan, dan lain-lain.

Adapun Sila Keadilan Sosial Bagi Seluruh Rakyat Indonesia, ialah:

1. Bersikap adil.

2. Menjaga keseimbangan antara hak dan kewajiban.

3. Menghormati hak-hak orang lain.

4. Suka memberi pertolongan kepada orang lain.

5. Tidak bersikap boros.

6. Menghargai hasil karya orang lain, dan lain-lain (Nasution, 2005: 30-36).

Semua eleman karakter yang terkandung dalam ke-lima sila di atas sesungguhnya merupakan transformasi dari karakter-karakter lokal bangsa Indonesia. Hampir semua suku, agama yang ada di Indonesia memiliki peran yang hampir sama pada butir-butir karakter bangsa kita. Karena itu, yang terpenting adalah bagaimana caranya menjelaskan konsep-konsep nasional tersebut lebih secara rinci dan memalui tindakan real melalui konsep lokalitas yang menjiwainya.

Jelas bahwa dalam pengembangan kurikulum, terutama yang berjiwa karakter yang menjadi filosofi dasarnya adalah pancasila. Selanjutnya yang yangan penting diperhatikan, dan ini secara tegas mengandung pentingnya kearifan lokal adalah asas sosiologis dalam pengembangan kurikulum. Dalam hal ini dijelaskan sebagai berikut:

Tiap masyarakat mempunyai norma-norma, adat kebiasaan yang tak dapat tiada harus dikenal dan diwujudkan anak dalam pribadinya lalu dinyatakannya dalam kelakuannya. Tiap masyarakat berlainan corak dan nilai-nilai yang dianutnya. Tiap anak akan berbeda latar belakang kebudayaannya. Perbedaan ini harus dipertimbangkan dalam kurikulum. Juga perubahan masyarakat akibat perkembangan ilmu pengetahuan dan teknologi merupakan faktor pertimbangan dalam kurikulum (Nasution, 2005: 13).

Karena selama ini unsur sosiologis dalam pendidikan karakter, terutama yang berkaitan dengan kearifan lokal secara implisit jarang diperhatikan. Karena itu, terutama sekali sekali lagi pada mata pelajaran yang substansial seperti PPKn, pendidikan agama, pendidikan sejarah, secara eksplisit perlu memperhatikan kearifan lokal dalam pengembangan kurikulum, baik dalam proses pembelajaran maupun dalam pendekatan. Pendekatan yang dikamsud dalam hal ini mulai dari sistem evaluasi, hubungan dengan keluarga siswa, pendekatan dalam pengembangan, dan lain sebagainya.

Asas-asas lain dalam pengembangan kurikulum, seperti asas psikologis dan asas organisatoris tidaklah kurang penting. Akan tetapi masud kami menonjolkan asas folosofis dan asas sosiologis karena berkaitan langsung dan erat dengan kearifan lokal 
Sejarah Lokal ..... - Lalu Murdi

sebagai basis dari kearifan nasional yang merupakan urat nadi dari pendidikan karakter itu sendiri. Jika filsafat menganung pedoman hidup dalam lokalitasnya, maka secara sosiologis berjalin erat dengan filosofis, karena filosofi inilah yang mengarahkan struktur maupun suprastruktur sosial masyarakat.

\section{KEARIFAN LOKAL DALAM TINJAUAN KEILMUAN}

Immanuel Kant (guru besar logika dan matematika: 1724-1804) menyebut dua realitas: yaitu dunia fenomena dan neumena. Bila hewan, tumbuh-tumbuhan dan alam tergolong dunia fenomena, dan makhluk jin, malaikat dan roh adalah dunia noumenal, maka manusia seperti dijelaskan oleh Kant memiliki dua dunia sekaligus, yaitu fenomena dan neumena (Agus Salim, 2001: 1-2). Keberadaan manusia yang memiliki dua sisi di atas, dalam penyelidikannya juga terdapat dua paradigma. Jika beberapa abad sebelumnya manusia pada umumnya hanya dilihat pada sisi fenomenanya dengan pendekatan kuantitatif yang bebas nilai. Dalam perkembangannya, karena manusia memiliki jiwa, maka dalam aspek neumenanya mulai didekatai dengan pendekatan kualitatif, yang merupakan paradigma baru dalam penyelidikan manusia yang terikat oleh nilai.

Pendekatan yang terikat oleh nilai dari suatu masyarakat ini dengan sendirinya mengarah pada ciri yang idiografis, sehingga jelas latar alamiah dari suatu masyarakat dinilai sesuai dengan sudut pandang masyarakat tersebut, dan bukan pandangan atau indikator-indikator dari luar. Karena itu, masyarakat harus dianalisa berdasarkan pandangan budaya, simbol, agama dan lain sebagainya yang mereka miliki. Artinya identitas lokal merekalah yang menjadi indikator kebenaran dalam melihatnya. Lebih dari hal tersebut, kalau lebih jauh melihat teori kritis, jelas didalamnya menganjurkan kearifan lokal dapat menjadi kritik idiologi umum atau apa pun yang sifatnya dapat merusak tatanan masyarakat (Hardiman, 2003).

Pengaruh positivisme pada abad ke-XIV sangat mendominasi perkembangan Ilmu Pengetahuan, bahkan hal ini terjadi sampai abad ke-XIX. Ilmu pengetahuan yang bebas nilai seperti dalam fisika, biologi, dan matematika di kutub yang berbeda, berpengaruh terhadap ilmu-ilmu sosial dan historis. Pengaruh positivisme dalam perkembangan ilmu-ilmu sosial dan historis tidaklah sepi dari perdebatan, dan inilah yang berpengaruh terhadap perkembangan Ilmu-ilmu sosial dan historis tersebut.

Bagi ilmu-ilmu sosial dan historis pada akhirnya oleh Windelband dan Rickert yang diperdalam oleh Dilthey dengan membedakan antara Geisteswissenschaften (ilmu- 
ilmu budaya) dengan Naturwissenchaften (ilmu alam), dijelaskan bahwa ilmu-ilmu budaya menghasilkan nilai, sedangkan ilmu-ilmu alam menghasilkan hukum, sehingga tidak memiliki relevansi nilai (Budi Hardiman, 2003: 14). Jadi yang membedakan antara ilmu-ilmu alam dengan ilmu-ilmu budaya adalah relevansi nilai yang ada di dalamnya.

Berdasarkan penjelasan di atas, jika dikaitkan dengan budaya lokal/ kearifan lokal dengan sendirinya bukan hanya sebagai falsafah hidup dari masyarakatkan melainkan merupakan bagian dari ilmu pengetahuan itu sendiri. Nilai-nilai kearifan yang mengandung karakter yang ada di dalamnya merupakan kebenaran bagi masyarakatnya. Karena itu, pada dasarnya kita tidaklah harus minder dengan budaya lokal yang kita miliki, justru akan sangat menarik jika masyarakat kita mampu mengangkan kearifan lokal tersebut dalam nilai kehidupan sehari-hari.

Dengan memahami logika di atas, maka beberapa hal positif yang bisa kita dapatkan:

1. Budaya lokal kita adalah bagian dari teori/generalisasi ilmu pengetahuan.

2. Memiliki nilai jual. Orang luar akan lebih tertarik dengan masyarakat yang bebeda kebudayaan, karena itu kuncinya adalah selalu menjaga kearifan lokal itu sendiri.

3. Tidak merasa minder dengan budaya luar, karena budaya kita merupakan bagian dari ilmu itu sendiri, dan memiliki nilai ekonomis.

4. Yang terpenting dari semuanya, terlepas dari nilai di atas, adalah fungsinya yang elegan dalam kehidupan sehari-hari.

\section{KESIMPULAN}

Indonesia merupakan negara kepulauan dengan kurang lebih 3000 pulau terbentang dari Sabang sampai Merauke. Pulau yang berjajar begitu banyaknya dihuni oleh sekitar 35 suku. Inilah yang membuat Indonesia menjadi negara yang menarik, dan sekaligus juga penting sebagai salah satu kajian. Dengan demikian banyaknya suku yang ada, sehingga negara Indonesia disebut sebagai negara yang multikultur. Setiap suku memiliki kearifan lokal tersendiri yang menjadi landasan filosofis bangsa Indonesia.

Masyarakat yang saat ini dalam istilah ekonominya tidak lagi memiliki logika ekonomi rasional, melainkan memiliki konsep ekonomi libidinal telah banyak berpengaruh terhadap pola pikir masyarakat yang cendrung hedonis, rakus dan tindakan 
Sejarah Lokal ..... - Lalu Murdi

negatif lainnya. Ini pula yang mempengaruhi masyarakat kita di Indonesia, tidak satu pun suku di Indonesia yang akan terlepas dari pengaruh dan perkembangan logika kehidupan abad ke-21 di atas. Karena itu, dibutuhkan penanaman nilai-nilai dasar dalam konsep lokalitas mulai sejak dini.

Pentingnya kearifan lokal dalam pendidikan karakter dikarenakan banyak faktor, diantaranya: 1) budaya lokal memiliki nilai yang lebih mudah dipahami oleh masyarakatnya; 2) untuk lebih meningkatkan identitas lokal yang memiliki nilai nasional sebagai basis pendidikan karakter itu sendiri; 3) budaya lokal yang dapat diinternalisasikan dalam kehidupan sehari-hari akan sangat menarik bagi orang luar dan akan memiliki nilai ekonomis; 4) yang lebih penting dari semuanya adalah nilai elegan dari kearifan lokal tersebut dapat dan selalu menjadi nilai hidup masyarakat kita.

Begitu pentingnya pendidikan karakter bagi bangsa kita dan masyarakat kita secara lokal tidaklah menutup kemungkinan untuk terbuka terhadap budaya dan kearifan lokal dari luar. Tentunya kita sadari bahwa tidak semua warisan budaya kita selalu sesuai dengan logoika zamannya, karena itu konsepnya satu yaitu "mengambil budaya yang baik dari masa lalu, dan menerima budaya luar yang baik dan sesuai dengan budaya ketimuran kita".

\section{DAFTAR PUSTAKA}

May, Abdurrachman. dkk. 1989. Tata Kelakuan di Lingkungan Pergaulan Keluarga dan Masyarakat Nusa Tenggara Barat. Mataram: Depdikbud.

Salim, Agus. 2001. Teori dan Paradigma Penelitian Sosial. Yogyakarta: Tiara Wacana Yogya.

Anonim. 2013. Pendidikan Karakter adalah Pendidikan untuk 275 Juta Penduduk Indonesia. Dalam http://www.pendidikankarakter.com/. Diakses 30-1-2014.

Anonim. 2013. Pengertian Pendidikan Karakter Secara Umum. Dalam http://hengkikristiantoateng.blogspot.com/. Diakses 30-1-2014.

Azra, Azyumardi. 2012. Pendidikan Karakter: Peran Sekolah dan Keluarga. Disampaikan pada seminar 'Pendidikan Karakter Teguhkan Pribadi Bangsa' yang terselenggara atas kerja sama PT Penerbit Erlangga dan Himpunan Mahasiswa Biologi, FMIPA, UNNES Semarang, Minggu 23 September, 2012. 
Sejarah Lokal ..... - Lalu Murdi

Hardiman, Budi. 2003. Kritik Idiologi: Menyingkap Kepentingan Pengetahuan Bersama Jurgen Habermas. Yogyakarta: Buku Baik.

Supardan, Dadang. 2011. Pengantar Ilmu Sosial: Sebuah Kajian Pendekatan Struktural. Jakarta: Bumi Aksara.

Suyatno, Suyono. Revitalisasi Kearifan Sebagai Upaya Penguatan Identitas Keindonesiaan. (http://badanbahasa.kemdikbud.go.id/).

Haroyono. 1995. Mempelajari Sejarah Secara Efektif. Jakarta: Pustaka Jaya.

Widja, I Gde. 1991. Sejarah Lokal Suatu Perspektif dalam Pengajaran Sejarah. Bandung: Angkasa.

Kuntowijoyo. 2005. Pengantar Ilmu Sejarah. Yogyakarta: Bentang.

Murdi, Lalu. 2014. Nilai Kebersamaan Masyarakat Sasak (Referesentasi Besiru, Banjar, dan Sistem Gotong Royong Lainnya. Selong: PUSAKANDA.

Ratmaja, Lalu. dkk. 2011. Lombok Selayang Pandang. Selong: PUSAKANDA.

Ratmaja, Lalu. 2011. Bahan Ajar Muatan Lokal Budaya Sasak. Selong: Gumi Sasak.

Samani, Muhlas. dan Hariyanto. 2011. Konsep dan Model Pendidikan Karakter. Bandung: Rosda.

Mursalim. 2013. Peran Generasi Muda dalam Melestarikan Budaya Serta Upaya Menjaga Kearifan Lokal. Dalam http://salamannennungeng.blogspot.com. Diakses 30-1-2014.

Nasikun. 2011. Sistem Sosal Indonesia. Jakarta: Rajawali Pers.

Nasution. 2005. Asas-Asas Kurikulum. Jakarta: Bumi Aksara.

Zuriah, Nurul. 2007. Pendidikan Moral \& Budi Pekerti dalam Perspektif Perubahan. Jakarta: Bumi Aksara.

Mudyahardjo, Redja. 2004. Filsafat Ilmu Pendidikan: Suatu Pengantar. Bandung: Remaja Rosdakarya.

Saptono. 2011. Dimensi-Dimensi Pendidikan Karakter: Wawasan, Strategi, dan Langkah Praktis. Jakarta: Esensi.

Soekanto, Sarjono. 1993. Kamus Sosiologi. Edisi Baru. Jakarta: Raja Grafindo.

Swasono, Sri Edi. 2014. Krisis Kepemimpinan Rezim Merampok Negara. Yogyakarta: UTS Press.

Sudirman, dkk. 2012. Mengenal Hukum Adat Sasak Zaman Kuno. Selong: PUSAKANDA. 